\title{
Senior High School Integrated Science Teachers' Perceptions of Classroom Assessment Practices in Selected Senior High Schools in Ghana
}

\author{
${ }^{1}$ Richard Acheampong, ${ }^{2}$ Eric Appiah-Twumasi, ${ }^{3}$ Daniel Nti, ${ }^{4}$ James Osei Kwabena \\ ${ }^{1,4}$ Science Department, Berekum College of Education \\ ${ }^{2}$ Akenten Appiah-Menka Unversity of Skills Training and Entrepreneurial Development, Ghana \\ ${ }^{3}$ Presbyterian Women College of Education, Aburi \\ *Corresponding author: appiatwumasi@gmail.com
}

\begin{abstract}
The study investigated senior high school Integrated Science teachers' perception of classroom assessment practises. The study employed a descriptive survey research designed to collect data from 20 Integrated Science teachers in a Municipality and a District in the Bono Region of Ghana. A questionnaire was used to collect quantitative data on teachers' perception of classroom assessment in Science. The data collected were computed into means, standard deviations and percentages. The study revealed that Integrated Science teachers selected for the study have positive perceptions towards classroom assessment. It also revealed that teachers perceived classroom assessment as tests that teachers give to their students at specific time intervals. While the teachers perceived classroom assessment as tests positively, they showed limited ability to use different methods and tools to assess their students' for teaching. The most frequent methods the teachers used to assess their students' learning were summative, formative and portfolio assessment. The study recommended that the support of stake-holders be sought to foster alternative assessment approaches in Senior High Schools in the study area. In addition, to help Integrated Science teachers develop positive perceptions towards classroom assessment in Science, it is recommended that inservice programmes should be organised for the teachers in the study area periodically.
\end{abstract}

Keywords: perception, senior high school (SHS), classroom assessment techniques (CATs)

\section{Introduction}

Assessment, defined as "a systematic process for gathering data about students' achievement," is an essential component of teaching (Dhindsa, Omar \& Waldrip, 2007). It gives a clear picture of how far students have understood the topic or the concept taught. Teachers can also interpret the effectiveness of their teaching methods and how useful their teaching and learning materials are from the students' assessment scores.

As Struyven, Duchy and Janssens (2005) argued, the impact of assessment is significantly observable on students' performance. The way teachers perceive classroom assessment determines the way and manner in which they conduct it (Struyven et al., 2005). Consequently, assessment in education was given more attention in the twentieth century (Madaus, Raczek, \& Clarke, 1997). It is within this period that assessment became more recognised as important within the educational sector.

Scriven (1967) proposes the use of "formative and summative" assessment to distinguish between the roles of evaluation. Hence, assessment is perceived to serve two purposes: formative, to improve instruction and summative, to measure students' achievement. The use of assessment to classify, predict and to select students for promotion has also changed to advance the process of teaching and learning in addition to accountability purposes (Gordon, 2008). This is especially the case when assessment checks or diagnoses the students' scholarly achievements to provide informational feedback on both the students' strengths and weaknesses as well as on the teachers' insight, effectiveness and efficiency.

According to Cavangah, Waldrip, Romanoski, Fisher and Dorman (2005), although teachers and 
administrators typically select assessment forms and tasks, the purpose of assessment varies among various stakeholders including students, teachers, parents, schools and policy makers. For example while teachers sometimes use assessment to determine how much and how well their students are learning, students on the other hand use assessment to reflect on their own learning and making adjustment so that they can achieve deeper understanding.

Despite the variations among the usage of assessment, Goodrum, Hacking and Rennie (2001) asserted that an assessment is an important component of teaching and learning process. It is one of the tools teachers can use to inform the teaching and the learning of their students. Unfortunately, the purpose of classroom assessment in most schools, seems to be confused and therefore not supporting learning (Ainscow, 1988; Stiggins, 2001; Swan, 1993).

There is a number of factors of Education that need to be understood and addressed if teachers are to support students to learn meaningfully. One such important factor is classroom assessment and teachers' perception behind it. Assessment is the systematic process of gathering data about students' performance over a period (Dhindsa, Omar, \& Waldrip, 2007). It gives a clear picture of students' performance both in strength and weakness. It also gives room for teachers to assess their mode of delivery, assessment tools and effectiveness of their instructional materials. The perception towards science may be expressed as peoples' like or dislike of Science as a subject. Such perception of Integrated science may be denoted as general positive or negative feeling towards the formal study of Science or Science as an area of research (Koballa \& Crowley, 1985).

However, in Ghana Senior High Schools, teachers have different perceptions of conducting assessment. Some teachers conduct assessment purposely to obtain marks to be recorded on the students' termly assessment form while others also conduct assessment to check students' strength and weaknesses as stated earlier. Besides, some teachers also conduct assessment and use it as a yardstick to punish the low achievers. This is more common at the lower grade and often in villages and hinterlands. The perceptions that these pupils acquire at the early stage of their education are more registered in their memory. It is carried on to higher levels and it is being put to use when they also grow up to become teachers. The perceptions of the teachers influence their assessment practises. Hence, the study sought to investigate Senior High School Integrated Science teachers' perceptions of classroom assessment and its alternative assessment techniques mostly employed by teachers in assessing their students.

The study was guided by the following research questions:

1. What are Senior High School Integrated Science teachers' perceptions of classroom assessment?

2. Which classroom assessment techniques are more frequently used by Senior High School Integrated Science teachers to assess their students learning?

\section{Research Methodology}

This section presents the description of the research design, target population and sampling procedure. It also discusses the instrumentation and gives a description of data analysis.

\section{Research Design}

This study used a descriptive survey research design through quantitative approach regarding Senior High School Integrated Science teachers' perceptions of classroom assessment.

\section{Population and Sampling}

The target population in this study was Integrated Science teachers in Bono Senior High Schools. However, the accessible population in this study comprised Integrated Science teachers in Sunyani Municipality and in Jaman North District. Two schools each from the Sunyani Municipality (urban) and Jaman North District (rural) were then purposively selected for the study. Five Integrated Science teachers from each school were then selected using simple random sampling techniques to represent the teachers involved in the study.

\section{Research Instrument}

The researchers adapted the Local Systematic Change Scale (LSC) instruments developed by Horizon Research In (HRI) to collect data on the Science teachers' perceptions of Science classroom assessment during instructions. The adopted LSC consisted of three items on a five-point Likert scale.

\section{Validity and reliability of the Instrument}

The adopted LSC research instrument was given to some experienced teachers for their comments and 
suggestions. To determine the reliability of the instruments, the instrument was field pilot-tested with 30 Senior High School Integrated Science teachers. The selected teachers were requested to respond to the items and re-respond to the items under the same conditions within seven days interval. Their responses were analysed and the researchers observed that the teachers gave similar responses to the items. This showed that the reliability of the LSC adopted instrument was acceptable in the Ghanaian Integrated Science Teaching context and for this reason, internal consistency of the instruments was ensured.

\section{Data analysis}

Data gathered were analysed descriptively with regards to the research questions. Specifically, frequencies, percentages, mean scores and Standard deviation were used to analyse data through the SPSS and Microsoft Excel.

\section{Findings and Discussion}

This section presents the findings and discussions of the study.

Research Question 1: What are Senior High School Integrated Science teachers' perceptions of classroom assessment?

A five-point Likert scale that tested perceptions of Integrated Science teachers towards classroom assessment composed of 3 items. Descriptive statistics were used to determine the mean scores, standard deviations, frequencies and percentages which were used for the analysis. In the analysis, "strongly disagree" and "disagree" were categorised as "disagree" while "strongly "agree" and "agree" were categorised as "agree." The results of the analysis are presented in Table 1. A mean score above or below 3 was considered positive and negative perception, respectively, while 3 was considered neutral.

Table 1: Description of Senior High Schools Integrated Science teachers' Perceptions of Classroom Assessment

\begin{tabular}{|c|c|c|c|c|c|}
\hline \multirow[t]{2}{*}{ Items } & \multicolumn{3}{|c|}{ Responses } & \multirow[t]{2}{*}{ MS } & \multirow[t]{2}{*}{ SD } \\
\hline & D & $\mathbf{N}$ & A & & \\
\hline Assessment is useful to me & $2(10)$ & $1(5)$ & 17(85) & 4.15 & 1.09 \\
\hline Assessment is useful to my students & $4(20)$ & $1(5)$ & $15(75)$ & 3.90 & 1.37 \\
\hline My teacher preparation programme provided various ways to assess students & $5(25)$ & $2(10)$ & 13(65) & 3.45 & 1.36 \\
\hline
\end{tabular}

*Percentage of responses in parentheses

Note: $D=$ Disagree, $N=$ Neutral, $A=$ Agree

The minimum and maximum frequencies of the teacher responses to the questionnaire under this section were 1 and 17 respectively and the mean scores ranged from $3.45(S D=1.36)$ to $4.15(S D$ =1.09). Generally, the teachers had a positive perception of classroom assessment. As most teachers, 17 (85\%) agreed that assessment was useful to them while $2(10 \%)$ of the teachers disagreed (item 1). In agreement with the results, the majority of the teachers indicated that the assessment gives teachers a picture of individual pupils' ability, helping teachers know if students have understood their lesson/topic. Others also indicated that assessments help teachers know their students' weakness and how to improve students' progress. In contrast, some teachers indicated that classroom assessment is a waste of time. They reasoned that the time spent conducting classroom test could be used to teach other aspects that may help students in their final examination.
The results as presented in the Table indicate that seventy-five per cent of the participants agreed on the statement, "assessment is useful to my students while $20 \%$ of the participants disagreed (item 2). Most respondents reasoned that classroom assessments give students a chance to remember what they learnt. Similarly, some respondents indicated that classroom assessments help students remember what they forget and keep them always alert. Most respondents also indicated that through classroom assessment, teachers easily identify students having problems, how to sort the problems and help students to test their understanding and to apply whatever they learnt.

However, some respondents provided that students of today had cultivated the habit of copying during an examination. Therefore, they reasoned that the true performances of students are unreflective of any assessment tool. Hence, there was no need to waste time conducting a class test. Moreover, some of the respondents said that the internally 
generated marks obtained by the students were not used by WAEC to form part of their final examination score. Hence, there was no need to conduct a class test.

When the teachers were further asked to indicate whether the teacher education programme they underwent provided various ways to assess students, $13(65 \%)$ of the teachers agreed while $5(25 \%)$ of the teachers disagreed (item 3 ). This suggested that the teachers had adequate skills or knowledge of conducting classroom assessment.

Again, when the teachers were asked to respond to a questionnaire that solicited their views on the meaning of assessment and how often they assessed their students, the following views were found. Almost half of the teachers involved in the study defined classroom assessment as a tool that a teacher uses to inform teaching and learning. Some of them further indicated that they assessed their students in about every lesson, while others indicated that they assessed their students once a month. Again, 5(25\%) of the teachers also defined assessment as all tests a teacher gives at the end of a topic or term, while the rest of the teachers defined classroom assessment as a process administering a test to students to assign grades and report to parents and officials. The responses given by the later teachers indicated that they assessed in every lesson, while the former teachers assessed their students every two weeks.

Research Question 2: Which classroom assessment techniques are more frequently used by Senior High School Integrated Science teachers' to assess their students learning?

A three- point Likert scale that tested classroom assessment techniques which are used frequently by Integrated Science teachers to assess students learning comprised 5 items. Descriptive statistics were used to determine mean scores, standard deviations and $P$ - value which were used for the analysis. The results of the analysis are presented in table 2. A mean score above or below 1 was considered frequently used and never used, respectively, while 1 was considered as sometimes.

Table 2: Distribution of mean scores and standard deviations of CAT

\begin{tabular}{llcc}
\hline Assessment Techniques & N & Mean & Std. Dev. \\
\hline Self-Assessment & 20 & .6000 & .68056 \\
Formative Assessment & 20 & 1.5000 & .51299 \\
Summative Assessment & 20 & 1.8500 & .36635 \\
Portfolio Assessment & 20 & 1.5500 & .51042 \\
Peer Assessment & 20 & .4500 & .51042 \\
\hline
\end{tabular}

Table 2 reports that the overall mean and standard deviation (SD) self-assessment were 0.6000 and 0.68056 respectively. For formative assessment $\mathrm{M}=$ 1.5000 and $\mathrm{SD}=0.51299$. For summative assessment, the overall values were $M=1.8500$ and $S D=0.36635$; for portfolio assessment $M=1.5500$ and $S D=0.51042$, and peer assessment $M=0.4500$ and $S D=0.51042$. Hence based on the descriptive statistics, the most frequently used assessment technique was summative assessment, followed by portfolio assessment and formative assessment. On the contrary, self-assessment and peer assessment were never used.

\section{Discussion of Results}

This section discusses the findings of the study as presented in the findings.

\section{Teachers' Perceptions of Classroom Assessment}

To confirm teachers' perception on classroom assessment, a statistical analysis was performed on the three items used to solicit teachers' views on the usefulness of assessment to them and to their students. Unsurprisingly, the mean score obtained for teachers perceptions on the three items was $M=$ 4.15, $M=3.90$ and $M=3.45$ (Table 1). This suggested that teachers had a positive perception on the usefulness of assessment to them and to their students. Also, it indicated that the teachers were exposed to various ways to assess students during their teacher education programme. This supports the findings of Chester \& Quilter (1998) that involving students in classroom assessment helps the teacher to know his or her weakness and how to improve students' progress.

\section{Assessment Techniques Frequently Used}

When the Integrated Science teachers were asked to express their views on the most frequently used classroom assessment technique, a statistical analysis was performed on five items; selfassessment, formative assessment, summative 
assessment, portfolio assessment and peer assessment. It was revealed that most frequently used classroom assessment techniques were summative assessment, followed by portfolio assessment and formative assessment of which selfassessment and peer assessment were never used (Table 2).

\section{Conclusion and Recommendations}

This section presents the conclusions of the study and then gives the recommendations.

\section{Conclusions}

Analysis of the results indicates that Integrated Science teachers in Ghana have a positive perception towards classroom assessment. It also revealed that the most frequent assessment methods the teachers used in assessing their students learning were summative, portfolio and formative assessment.

\section{Recommendation}

The study recommends that school managers should help science teachers develop positive attitude towards classroom assessment. Furthermore, there is need to upgrade the teachers on assessment methods. Finally, there is need to conduct in service training regularly for capacity building among the teachers under investigation.

\section{Reference}

Ainscow, M. (1988). Beyond the Eyes of the Monster: Analysis of the Recent Trends in Assessment and Recording. Support for Learning, 3 (3), $56-64$.

Cavangah, R. F., Waldrip, B. G., Romanoski, J. T., Fisher, D. L., \& Dorman, J. P. (2005). December). Measuring Student Perceptions of Classroom Assessment, Paper Presented at the Annual Meeting of the Australian Association for Research in Education, Parramatta, Australia.

Chester, C., \& Quilter, S. M. (1998). In-service Teachers' Perceptions of Educational Assessment. Journal for Research in mathematics Education, 33 (2), 210-236.
Dhindsa, H., Omar, K., \& Waldrip, B. (2007, August 1). Upper Secondary Bruneian Science Students Perceptions of Assessment. International Journal of Science Education, 29 (10), $1281-1280$.

Goodrum, D., Hackling, M., \& Rennie, L. (2001). The Status and Quality of Teaching and Learning of Science in Australia Schools. Canberra: Department of Education, Training and Youth Affairs.

Gordon, E. W. (2008). The transformation of Key Beliefs that have guided a Century of Assessment. In C. A. Dwyer (Ed.). The future of Assessment: Shaping Teaching and Learning. (pp. 53 - 82). New York: Lawrence Erlbaum Associates.

Koballa, T. R., \& Crawley. F. E. (1985). The influence of attitude on science teaching and learning. School Science and Mathematics, 85(3) 222 -232 .

Madaus, G. F., Raczek, A., \& Clarke, M. M. (1997). The Historical and Policy Foundations of Assessment Movement. In A. L. Goodwin. Assessment for Equity and Inclusion: Embracing all our Children, New York: Routledged.

Scriven, M. (1967). The Methodology of Evaluation (vol 1). Washington, DC: American Educational Research Association.

Stiggins, R. J. (2001). Students-Involved Classroom Assessment ( $3^{\text {rd }}$ ed). Upper Saddle River, NJ. Merrill Prentice Hall.

Struyven, K., Dochy, F., \& Jnssens, S. (2005). Students' Perceptions about Evaluation and Assessment in Higher Education: A Review. Assessment and Evaluation in Higher Education, 30 (4), 325-341.

Swan, M. (1993). Assessment for the Mathematics Classroom. In Assessment in the Mathematics Classroom. Reston: National Council of Teachers of Mathematics. 